Article

\title{
Techno-Economic Analysis of Pressurized Oxy-Fuel Combustion of Petroleum Coke
}

\author{
Hachem Hamadeh ${ }^{1}$, Sannan Y. Toor ${ }^{1}$, Peter L. Douglas ${ }^{1}$, S. Mani Sarathy ${ }^{2}$, Robert W. Dibble ${ }^{2}$ \\ and Eric Croiset $1, * \mathbb{B}$ \\ 1 Chemical Engineering Department, University of Waterloo, Waterloo, Ontario N2L 3G1, Canada; \\ h2hamadeh@uwaterloo.ca (H.H.); sannan.toor@uwaterloo.ca (S.Y.T.); peter.douglas@uwaterloo.ca (P.L.D.) \\ 2 Clean Combustion Research Center, Physical Sciences and Engineering Division, King Abdullah University \\ of Science and Technology, Thuwal 23955-6900, Saudi Arabia; mani.sarathy@kaust.edu.sa (S.M.S.); \\ robert.dibble@kaust.edu.sa (R.W.D.) \\ * Correspondence: ecroiset@uwaterloo.ca
}

Received: 28 April 2020; Accepted: 1 July 2020; Published: 4 July 2020

Abstract: Petroleum coke (petcoke) is a by-product of heavy petroleum refining, with heating values comparable to that of coal. It is readily available in oil-producing countries such as the United States of America (USA) and the Kingdom of Saudi Arabia (KSA) at minimum costs and can be used as an inexpensive fossil fuel for power generation. Oxy-petcoke combustion is an attractive $\mathrm{CO}_{2}$ capture option as it avoids the use of additional absorption units and chemicals, and results in a $\mathrm{CO}_{2}+\mathrm{H}_{2} \mathrm{O}$ flue gas stream that is compressed and dehydrated in a $\mathrm{CO}_{2}$ capture and purification unit $\left(\mathrm{CO}_{2} \mathrm{CPU}\right)$. The additional cost of the $\mathrm{CO}_{2} \mathrm{CPU}$ can be reduced through high pressure combustion. Hence, this paper reports a techno-economic analysis of an oxy-petcoke plant with $\mathrm{CO}_{2}$ capture simulated at pressures between 1 and 15 bars in Aspen Plus ${ }^{\mathrm{TM}}$ based on USA and KSA scenarios. Operating at high pressures leads to reduced equipment sizes and numbers of units, specifically compressors in $\mathrm{CO}_{2} \mathrm{CPU}$, resulting in increased efficiencies and decreased costs. An optimum pressure of $\sim 10$ bars was found to maximize the plant efficiency $(\sim 29.7 \%)$ and minimize the levelized cost of electricity (LCOE), cost of $\mathrm{CO}_{2}$ avoided and cost of $\mathrm{CO}_{2}$ captured for both the USA and KSA scenarios. The LCOE was found to be moderately sensitive to changes in the capital cost $(\sim 0.7 \%$ per $\%)$ and increases in cost of petcoke ( $\sim .5 \%$ per USD/tonne) and insensitive to the costs of labour, utilities and waste treatment.

Keywords: $\mathrm{CO}_{2}$ capture; oxy-fuel combustion; pressurized combustion; petroleum coke; AspenPlus $^{\mathrm{TM}}$ simulation

\section{Introduction}

According to the 2016 Paris Agreement, crucial steps are required to mitigate the emissions of greenhouse gases (GHG) and thereby limit the earth temperature increase to $2{ }^{\circ} \mathrm{C}$ above pre-industrial levels. One option is to capture $\mathrm{CO}_{2}$ from fossil fuel combustion processes. Due to increased heavy oil production, petroleum coke (petcoke), a by-product of petroleum refining, is readily available in oil-producing countries at economical costs [1]. In addition, petcoke has a high heating value, which makes it a viable option for economical energy production [2].

There are three main approaches to capture $\mathrm{CO}_{2}$ in fossil fuel combustion processes [3]:

1. Post combustion: $\mathrm{CO}_{2}$ is removed from the flue gas using techniques such as absorption.

2. Pre combustion: Pre-reformed fuel is used, where, after reformation, $\mathrm{CO}_{2}$ is removed from the fuel before combustion.

3. Oxy-fuel combustion: Fuel is combusted in oxygen ( $>95 \%$ ) instead of air, leading to high $\mathrm{CO}_{2}$ concentrations in the flue gas due to the near absence of nitrogen in the combustion process. 
Post and pre-combustion routes require additional units such as absorption/adsorption towers, cryogenic distillation or membrane separators for $\mathrm{CO}_{2}$ capture. On the other hand, in oxy-fuel combustion, the flue gas comprises mostly $\mathrm{CO}_{2}$ and $\mathrm{H}_{2} \mathrm{O}$, and only dehydration is needed to produce a high purity $\left(>90 \% \mathrm{CO}_{2}\right)$ stream [4]. The absence of large quantities of nitrogen (from the air in air-fired plants) reduces the flow rate of flue gas and hence the size of downstream units, subsequently reducing equipment costs [5]. These characteristics make oxy-fuel combustion an attractive carbon capture and storage (CCS) technique.

Although oxy-fuel combustion is promising, associated challenges remain. Additional air separation units (ASU) are required, typically working at 5 to 10 bars [6], for the production of a high purity $(>95 \%) \mathrm{O}_{2}$ stream, which leads to increased initial investment and manufacturing costs. The ASU is amongst the highest power consuming units of an oxy-fuel plant [4]. Another option is to operate the plant at high pressure, as this can further decrease the equipment cost by promoting the use of smaller equipment and off-set the power requirement of the downstream $\mathrm{CO}_{2}$ capture and purification unit $\left(\mathrm{CO}_{2} \mathrm{CPU}\right)[4,7]$. A higher pressure operation also allows for recovering the latent heat from high moisture flue gases, as pointed out by Hong et al. [8], Zebian et al. [9], and Soundarajan and Gundersen [10], who all simulated pressurized oxy-combustion systems in Aspen Plus, and who all have shown that pressurized oxy-fuel combustion leads to higher efficiencies than for the atmospheric case. Gopan et al. [11] presented and simulated in Aspen Plus a concept of a staged pressurized oxy-combustion process. They found that the net efficiency of their process is about $7 \%$ higher than "conventional" atmospheric oxy-fuel combustion systems. More recently, Chen et al. [12] and Shi et al. [13] presented simulation of pressurized oxy-fuel combustion, but in the context of circulating fluidized bed. An interesting result from most of the studies on pressurized oxy-fuel combustion simulation reported here is that the net plant efficiency is usually found to be a maximum at an operating pressure of around 10 bars.

As a first step to assess its viability, system modelling for oxy-fuel combustion using petcoke is required. The main objective of this paper is therefore to conduct a techno-economical study of using petroleum coke as a feedstock to generate power through pressurized oxy-fuel combustion technology with $\mathrm{CO}_{2}$ capture. This study considers two country-scenarios where petcoke is readily available: the United States of America (USA) and the Kingdom of Saudi Arabia (KSA). Several researchers have presented techno-economic studies on coal-based integrated oxy-fuel combustion systems including an ASU, a combustion boiler section (CBS), a balance of plant (BOP), and $\mathrm{CO}_{2} \mathrm{CPU}[7,14-16]$. However, to the authors' knowledge, no work has been published pertaining to oxy-fuel combustion of petcoke. The present paper presents a techno-economic Aspen Plus ${ }^{\mathrm{TM}}$ model of an integrated high-pressure oxy-combustion power plant that uses petcoke as fuel. The ASU, BOP and $\mathrm{CO}_{2} \mathrm{CPU}$ are based on the work of Fu and Gundersen [7], the US Department of Energy [17], and Shafeen [15], respectively.

\section{Methodology}

For this study, the fuels are petcoke and Illinois No. 6 coal (coal). Table 1 summarizes the composition of both fuels used here. Illinois No. 6 coal was chosen because it was used in several oxy-coal combustion studies, allowing for direct comparison of the results of our base case atmospheric pressure oxy-coal combustion model with those of these studies [7,17].

\subsection{Process Simulation Model}

The integrated oxy-petcoke plant comprises of four major sections; the ASU, CBS, the BOP, and the $\mathrm{CO}_{2} \mathrm{CPU}$, as shown in Figure 1. The oxygen stream from the ASU is used in the CBS for petcoke combustion to produce a hot flue gas. This hot flue gas is used to produce steam, and then electric power in the BOP. The cooled flue gas from the $\mathrm{CBS}$ is then fed to the $\mathrm{CO}_{2} \mathrm{CPU}$ to produce a concentrated high-pressure $\mathrm{CO}_{2}$ stream. 
Table 1. Composition of coal and petcoke.

\begin{tabular}{ccc}
\hline Proximate Analysis (Dry Basis) & Coal & Petcoke \\
\hline Fixed Carbon & $49.7 \%$ & $85.9 \%$ \\
Volatile Matter & $39.4 \%$ & $11.9 \%$ \\
Ash & $10.9 \%$ & $2.2 \%$ \\
\hline Ultimate Analysis (water ash free) & & \\
\hline Carbon & $71.7 \%$ & $80.8 \%$ \\
Hydrogen & $5.1 \%$ & $3.5 \%$ \\
Sulphur & $2.8 \%$ & $3.1 \%$ \\
Nitrogen & $1.4 \%$ & $1.6 \%$ \\
Chlorine & $0.3 \%$ & $0 \%$ \\
Ash & $10.9 \%$ & $2.2 \%$ \\
Oxygen (by difference) & $7.8 \%$ & $8.8 \%$ \\
\hline Heating value (HHV) (MJ/kg) & 27.2 & 34.6 \\
\hline
\end{tabular}

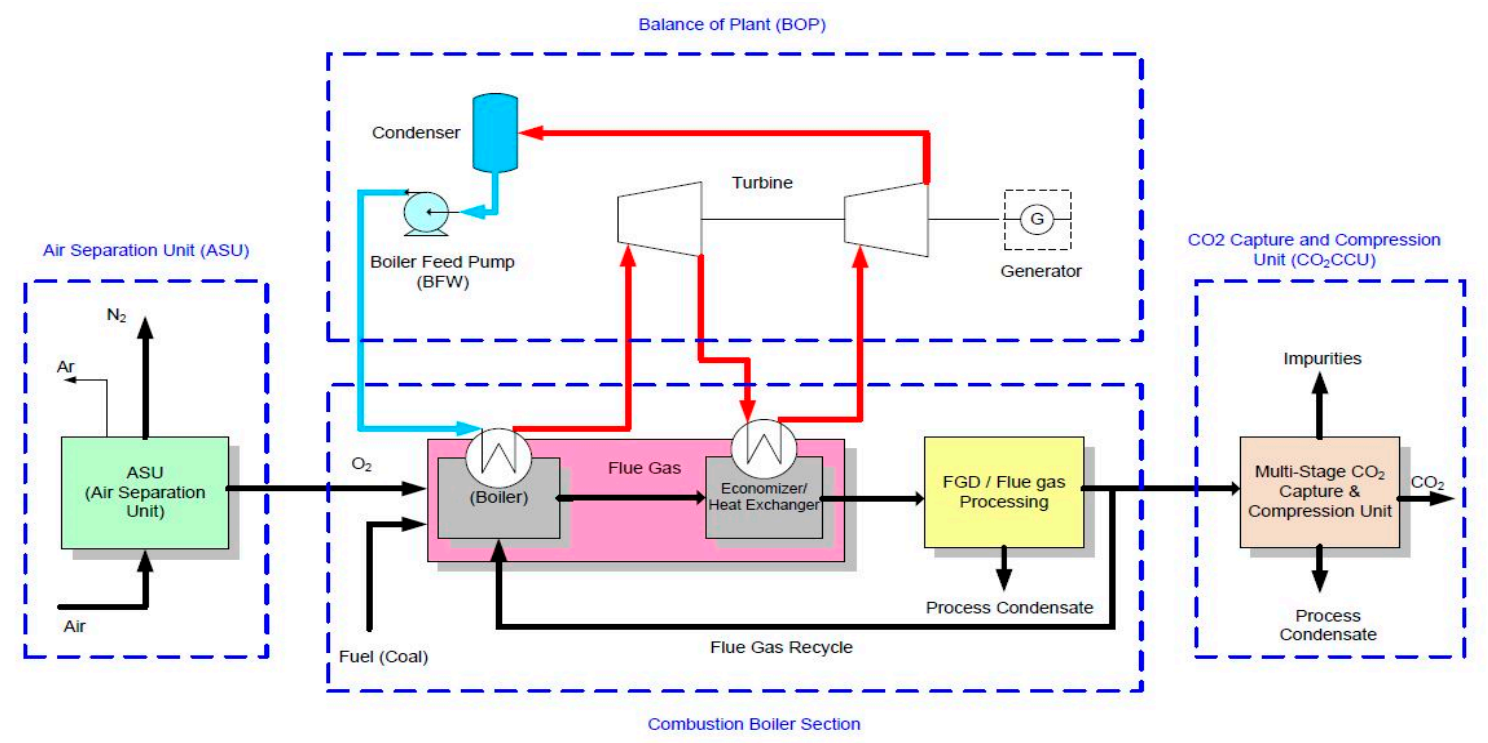

Figure 1. Typical oxy-fuel power plant [15].

Aspen Plus ${ }^{\mathrm{TM}} 8.8$ was used to model this system. The ASU is adapted from a study by Fu and Gundersen [7], referred to as Norwegian University of Science and Technology (NTNU) throughout the text. The CBS and BOP sections are based on a study by the US DOE on the oxy-combustion of pulverized coal [17]. The $\mathrm{CO}_{2} \mathrm{CPU}$ was developed based on a patented design by Zanganeh and Shafeen [18]. Finally, an economic model, based on literature by Towler and Sinnott [19] and Turton et al. [20], was used to assess the economics of the plant.

In all simulations presented in this study, what remains constant is the gross power output of the plant (792 MW) or, said differently, the rate of heat transferred from the combustion boiler section to the balance of plant (1877 $\left.\mathrm{MW}_{\text {th }}\right)$. Those values were calculated based on an atmospheric pressure oxy-coal combustion simulation for a net power output of around 550 MW burning Illinois No. 6 coal $[7,17]$. The adiabatic flame temperature was set at $1830^{\circ} \mathrm{C}$ for coal and $1866{ }^{\circ} \mathrm{C}$ for petcoke, as determined by running separate combustion simulations in air. The primary focus of this work is to explore oxy-fuel combustion of petcoke from atmospheric to pressurized conditions followed by carbon capture. Since the operating pressure does not affect the BOP and requires only the installation of one compressor at the ASU outlet to bring the oxygen stream up to the operating pressure, descriptions of only the CBS and $\mathrm{CO}_{2} \mathrm{CPU}$ are given in the text. The ASU [21,22] and BOP [23,24] are commonly used units with information readily available. The overall Aspen Plus flowsheet is shown in Figure 2 
and includes three "hierarchy" blocks representing detailed models of the ASU, BOP and $\mathrm{CO}_{2} \mathrm{CPU}$ sections. Detailed descriptions of the ASU, BOP, and $\mathrm{CO}_{2} \mathrm{CPU}$ are provided in the supplementary information along with their unit flowsheets (Figures S1-S3).

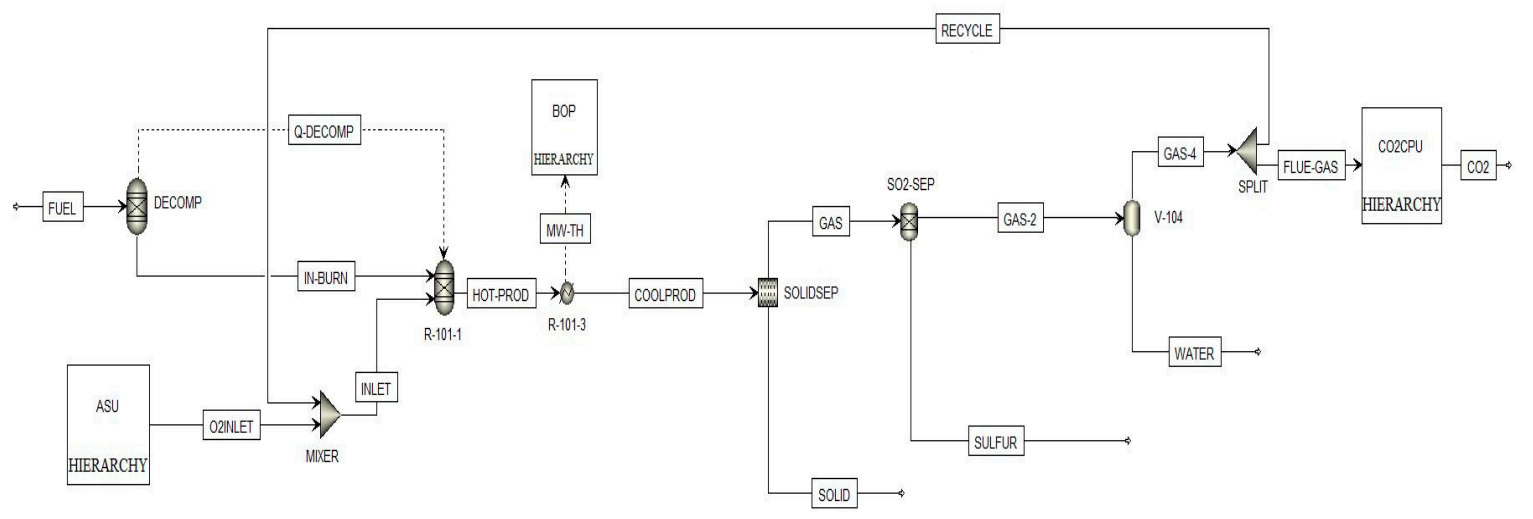

Figure 2. Overall Aspen Plus oxy-combustion flowsheet for coal and petcoke.

\subsubsection{Combustion Boiler Section (CBS)}

To simulate the combustor, combinations of RYield and RGibbs models were used. RYield simulates the decomposition of the solid fuel components based on its ultimate analysis, while RGibbs calculates the chemical equilibrium of the combustion reaction by minimizing the system's Gibbs free energy [25,26]. In Figure 2, FUEL enters the DECOMP (RYield) and then the R-101-1 (RGibbs), simulating the combustion process. Along with FUEL, INLET enters R-101-1 carrying the $\mathrm{O}_{2}$ with which the fuel is reacting. INLET is a mixture of $\mathrm{O}_{2}$ (from the ASU) and the flue gas recycle stream (RECYCLE) and is made up of about $26 \% \mathrm{O}_{2}, 54 \% \mathrm{CO}_{2}, 14 \% \mathrm{H}_{2} \mathrm{O}$ and $6 \%$ other species, essentially $\mathrm{Ar}$ and $\mathrm{N}_{2}$. The combustion inside R-101-1 takes place at $1866^{\circ} \mathrm{C}$ (in the case of petcoke), which means that the resulting flue gas, HOT-PROD, comes out of R-101-1 at this temperature. To maintain the boiler temperature at this temperature, a design spec was used to regulate the recycle ratio of the flue gas produced. Similarly, a design spec was used to maintain 3\% excess oxygen (dry basis) to ensure complete combustion by controlling the flow through the ASU. HOT-PROD then passes through a heat recovery steam generator, represented by $\mathrm{R}-101-3$, where it is cooled to $176^{\circ} \mathrm{C}$. A temperature of $176^{\circ} \mathrm{C}$ is needed to avoid any condensation before the stream (COOLPROD) enters the bag filter, SOLIDSEP, where $99.8 \%$ of particulate matter is removed. The temperature is further increased to $185^{\circ} \mathrm{C}$ as the stream enters a separator unit (SO2-SEP) that represents a flue gas desulphurization (FGD) unit, removing $98 \%$ of the sulphur dioxide $\left(\mathrm{SO}_{2}\right)$ present in the flue gas, GAS-1 [17]. After removing $\mathrm{SO}_{2}$, the stream (GAS-2) enters a flash separator (V-104) to remove some $\mathrm{H}_{2} \mathrm{O}$ through condensation, resulting in a flue gas that is about $75 \% \mathrm{CO}_{2}, 16 \% \mathrm{H}_{2} \mathrm{O}, 2.6 \% \mathrm{O}_{2}$ and $2.8 \% \mathrm{Ar}$ (GAS-4). Approximately, $70 \%$ to $75 \%$ of GAS-4 is recycled back into R-101-1 as RECYCLE to maintain the required combustion temperature; and the remaining FLUE-GAS is sent into the $\mathrm{CO}_{2} \mathrm{CPU}$ for further processing, as will be described later in this section.

\subsection{2. $\mathrm{CO}_{2}$ Capture and Purification Unit $\left(\mathrm{CO}_{2} \mathrm{CPU}\right)$}

The $\mathrm{CO}_{2} \mathrm{CPU}$ section is shown in Figure 3 .

The $\mathrm{CO}_{2} \mathrm{CPU}$ is comprised of two sections: the first section consists of multistage compression with intercooling and the second section consists of cooling and compression to bring the pressure of the final concentrated $\mathrm{CO}_{2}$ stream to 110 bars. The first section contains four compressors: the first three compressors sequentially take the flue gas (FLUE-GAS) to 5, 10 and 15 bars. The flue gas is then mixed with a recycle stream and compressed to 30 bars using the fourth compressor. The stream temperature is $35^{\circ} \mathrm{C}$ at the end of the compressor train. To completely remove water and impurities, the second section couples two multi-stream heat exchangers and expanders to cool down the stream 
to $-38{ }^{\circ} \mathrm{C}$. Impurities are then removed using flash separation before the final stream is pressurized to 110 bars. More information can be found in [15]. It is important to mention that when the operating pressure of the CBS section is increased, it reduces the need for compressors in the first section of the $\mathrm{CO}_{2} \mathrm{CPU}$. For example, when the boiler operates at 5 bars, the first compressor will be removed in the $\mathrm{CO}_{2} \mathrm{CPU}$. Therefore, the operating pressure considered in the CBS section is varied between 1 and 15 bars.

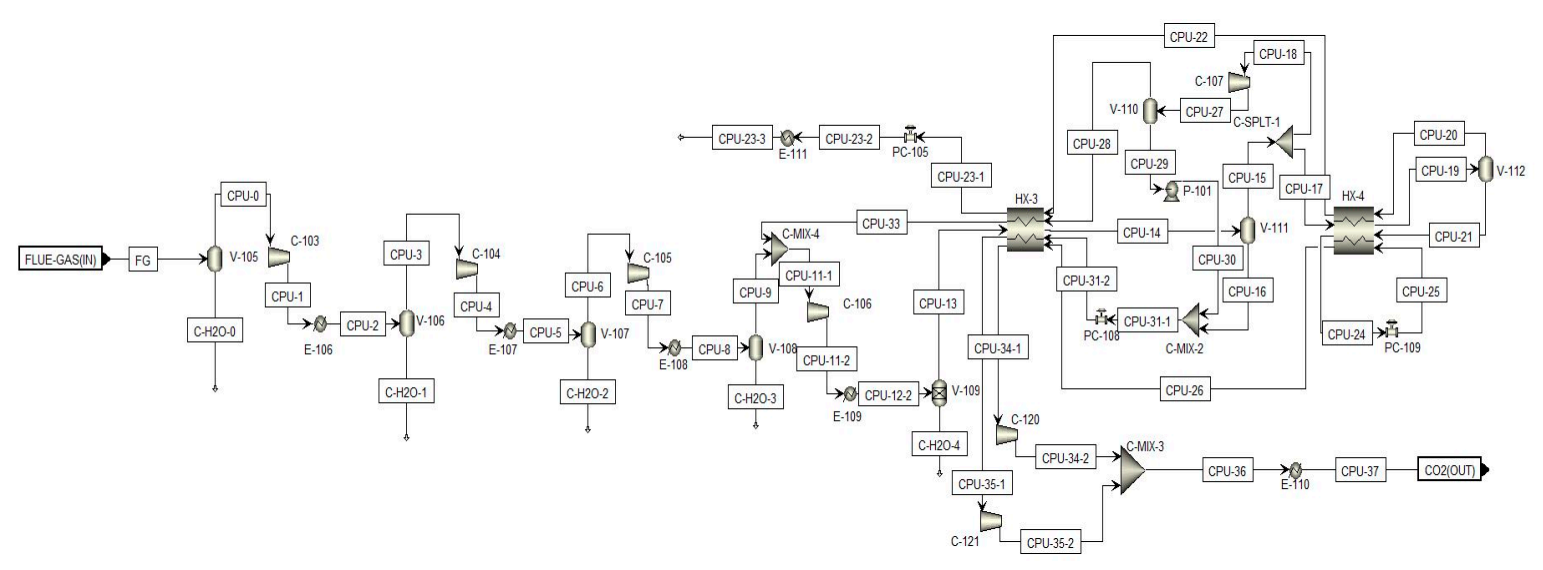

Figure 3. Aspen Plus $\mathrm{CO}_{2} \mathrm{CPU}$ flowsheet.

\subsection{Economic Model}

While various economic assessments of oxy-fuel developments are available, differences result from the calculation basis, variation in costs, policies and legislation among jurisdictions. With no commercial oxy-fuel plants available yet, there is also considerable uncertainty in regards to costs, efficiency and $\mathrm{CO}_{2}$ utilization [27]. However, comprehensive reviews comparing techno-economic studies of carbon capture technologies published by Kanniche et al. [28] and Rubin et al. [29] assessed the current cost of $\mathrm{CO}_{2}$ capture technologies in comparison to government reports published up to a decade ago.

The main outcomes of this economic model are the levelized cost of electricity ( $L C O E)$, cost of $\mathrm{CO}_{2}$ avoided, and cost of $\mathrm{CO}_{2}$ captured as calculated by Equations (1), (3) and (4) respectively. All costs are reported in 2017 US dollars (USD).

$$
L C O E=\frac{C C F_{P}(\text { Total Capital Cost })+0.16 F C I+1.55 C_{O L}+1.03\left(C_{R M}+C_{W T}+C_{U T}\right)}{C F(E)}
$$

$C C F_{P}$ is the capital charge factor discounted over the plant's lifetime, which is calculated using Equation (2).

$$
C C F_{P}=\frac{i(1+i)^{n}}{(1+i)^{n}-1}
$$

where $i$ is the fractional discount rate, and $n$ is the plant's lifetime in years. FCI is the fixed capital investment (USD) which is the total investment cost of the plant, $C_{O L}$ is the annual cost of labour (USD/year), $C_{R M}$ is the annual cost of raw material (USD/year), $C_{W T}$ is the annual cost of waste treatment (USD/year), $C_{U T}$ is the annual cost of utilities (USD/year), CF is the capacity factor and $E$ is the electrical power throughput $\left(\mathrm{MW}_{\mathrm{e}}\right)$.

Cost of $\mathrm{CO}_{2}$ Avoided

$$
\begin{gathered}
=\frac{L C O E-L C O E^{\prime}}{\mathrm{CO}_{2} \text { Emitted without } \mathrm{CO}_{2} \text { Capture }-\mathrm{CO}_{2} \text { Emitted with } \mathrm{CO}_{2} \text { Capture }} \\
\text { Cost of } \mathrm{CO}_{2} \text { Captured }=\frac{L C O E-L C O E^{\prime}}{\mathrm{CO}_{2} \text { Captured }}
\end{gathered}
$$


$L C O E^{\prime}$ is the levelized cost of electricity for an atmospheric air-fired power plant without $\mathrm{CO}_{2}$ capture discounted at the same interest rate and time-period as the LCOE. In Equations (3) and (4) the $\mathrm{CO}_{2}$ emitted and captured terms are in metric tonnes/year.

The procedure for calculating FCI and cost of manufacturing (COM) is taken from [20]. The COM is composed of direct costs (e.g., labour, raw materials), fixed costs (e.g., depreciation) and general expenses (e.g., administration costs) and is calculated using Equation (5), where $C_{O L}$ is the cost of operating labour, $C_{U T}$ the cost of utilities, $C_{W T}$ the cost of waste treatment and $C_{R M}$ the cost of raw materials. $C_{U T}$ was taken as $1.7 \%$ of installed cost [30].

$$
\mathrm{COM}=0.280 \mathrm{FCI}+2.73 \mathrm{C}_{O L}+1.23\left(\mathrm{C}_{U T}+\mathrm{C}_{W T}+\mathrm{C}_{R M}\right)
$$

These require specifications pertaining to the size of equipment, material of equipment, and cost of raw material, labour and utilities. For brevity, cost of equipment, sizing, and material used are provided in the supplemental information (Table S1). Since the economic analysis was performed for the USA and the KSA, the discount rate, cost of labour, and raw material were different in both cases. Table 2 provides a summary of the assumptions used in the economic model.

Table 2. Assumptions for the economic model.

\begin{tabular}{ccc}
\hline Particular & USA & KSA \\
\hline Plant Net Output (MW $\mathrm{MW}_{\mathrm{e}}$ [17] & 550 & 550 \\
Capacity Factor (\%) [17] & 85 & 85 \\
Economic Life of Plant (years) [17] & 20 & 20 \\
Discount Rate (\%) [20,31] & 17.5 & 5 \\
Average Hourly Wage (USD/h) [32] & 31.7 & 18.5 \\
Selling Price of Electricity (cent/kWh) [32] & 12 & 6.7 \\
Selling Price of Captured CO $(\mathrm{HSD} /$ tonne) [32] & 20 & 20 \\
Cost of Petcoke (USD/tonne) & 0 & 0 \\
\hline
\end{tabular}

\section{Results and Discussion}

\subsection{Simulation Results}

\subsubsection{Atmospheric Oxy-Petcoke Combustion}

Using the flowsheet and conditions discussed in the methodology section, the oxy-combustion of petcoke and coal were simulated at a combustion temperature of $1866^{\circ} \mathrm{C}$ and $1830^{\circ} \mathrm{C}$, respectively. The main simulation results are shown in Table 3, while Table 4 presents the composition of the flue gas produced by the combustion before being cleaned, dried and processed.

Table 3. Comparison of simulation results for the oxy-combustion of coal and petcoke.

\begin{tabular}{cccc}
\hline Parameter & Coal & Petcoke & Petcoke \\
\hline Adiabatic Flame Temperature, AFT $\left({ }^{\circ} \mathrm{C}\right)$ & 1830 & 1830 & 1866 \\
ASU Flow $(\mathrm{kg} / \mathrm{h})$ & 602,713 & 545,523 & 545,304 \\
Fuel Flow $(\mathrm{kg} / \mathrm{h})$ & 247,829 & 212,707 & 213,158 \\
Flue Gas Flow to CO 2 CPU $(\mathrm{kg} / \mathrm{h})$ & 752,661 & 727,712 & 728,077 \\
Recycle Ratio $(\%)$ & 74.5 & 76.2 & 75.6 \\
$\mathrm{CO}_{2}$ Purity $(\%)$ & 96.4 & 96.4 & 96.4 \\
ASU Power Consumption (MW) & 132 & 119.9 & 119.8 \\
$\mathrm{CO}_{2}$ CPU Power Consumption (MW) & 93.7 & 90.8 & 91.3 \\
Auxiliaries (MW) & 25.3 & 25.3 & 25.3 \\
Gross Power (MW) & 792.1 & 792.1 & 792.1 \\
Net Power (MW) & 541 & 556.2 & 557.0 \\
Net Efficiency $(\%)$ & 28.9 & 27.2 & 27.1 \\
\hline
\end{tabular}


Table 4. Composition of the flue gas stream after combustion (HOT-PROD in Figure 2) for oxy-coal and oxy-petcoke combustion.

\begin{tabular}{cccc}
\hline Component & Mole Fraction (\%) & & \\
\hline & Coal & Petcoke & Petcoke \\
\hline & (AFT 1830 $\left.{ }^{\circ} \mathbf{C}\right)$ & (AFT 1830 ${ }^{\circ}$ C) & (AFT 1866 ${ }^{\circ}$ C) \\
\hline $\mathbf{O}_{2}$ & 2.4 & 2.5 & 2.5 \\
$\mathbf{C O}$ & 1.3 & 1.4 & 1.8 \\
$\mathbf{C O}_{2}$ & 71.7 & 74.1 & 73.7 \\
$\mathbf{H}_{\mathbf{2}} \mathbf{O}$ & 19.2 & 16.6 & 16.6 \\
$\mathbf{S O}_{2}$ & 0.3 & 0.3 & 0.3 \\
$\mathbf{N}_{\mathbf{2}}$ & 2.1 & 2.2 & 2.2 \\
$\mathbf{A r}$ & 2.6 & 2.8 & 2.8 \\
\hline
\end{tabular}

Table 3 shows that despite a higher net power in the case of petcoke, the net efficiency for oxy-petcoke at $1 \mathrm{~atm}$ is lower than that of oxy-coal combustion by nearly $2 \%$. This is due to the higher heating value of petcoke than that of coal. The higher net power output achieved with petcoke is due to the lower oxygen requirement (hence lower ASU duty), and lower gas flow rate to be treated in the $\mathrm{CO}_{2} \mathrm{CPU}$ (hence lower $\mathrm{CO}_{2} \mathrm{CPU}$ duty). However, the case of petcoke requires a higher recycle ratio. Comparison between the two petcoke scenarios reveals the effect of the AFT on the plant performance. The lower AFT $\left(1830^{\circ} \mathrm{C}\right)$ leads to a slightly higher net efficiency $(27.2 \%$ vs. $27.1 \%)$ than at the higher AFT of $1866^{\circ} \mathrm{C}$. The reason is that when decreasing the AFT, the ASU duty remains almost unchanged while $\mathrm{CO}_{2} \mathrm{CPU}$ duty decreases because of the larger recycle ratio at lower AFT.

\subsubsection{Pressurized Oxy-Petcoke Combustion}

Oxy-petcoke combustion was simulated at operating pressures between 1 and 15 bars by increasing the pressure at which the oxygen and fuel are introduced into the system. Since the ASU and $\mathrm{CO}_{2} \mathrm{CPU}$ are the major power-consuming units, they have the largest effect on plant efficiency. Figure 4 illustrates the power consumption of the $\mathrm{ASU}, \mathrm{CO}_{2} \mathrm{CPU}$, net power and the net efficiency with changes in the operating pressure.

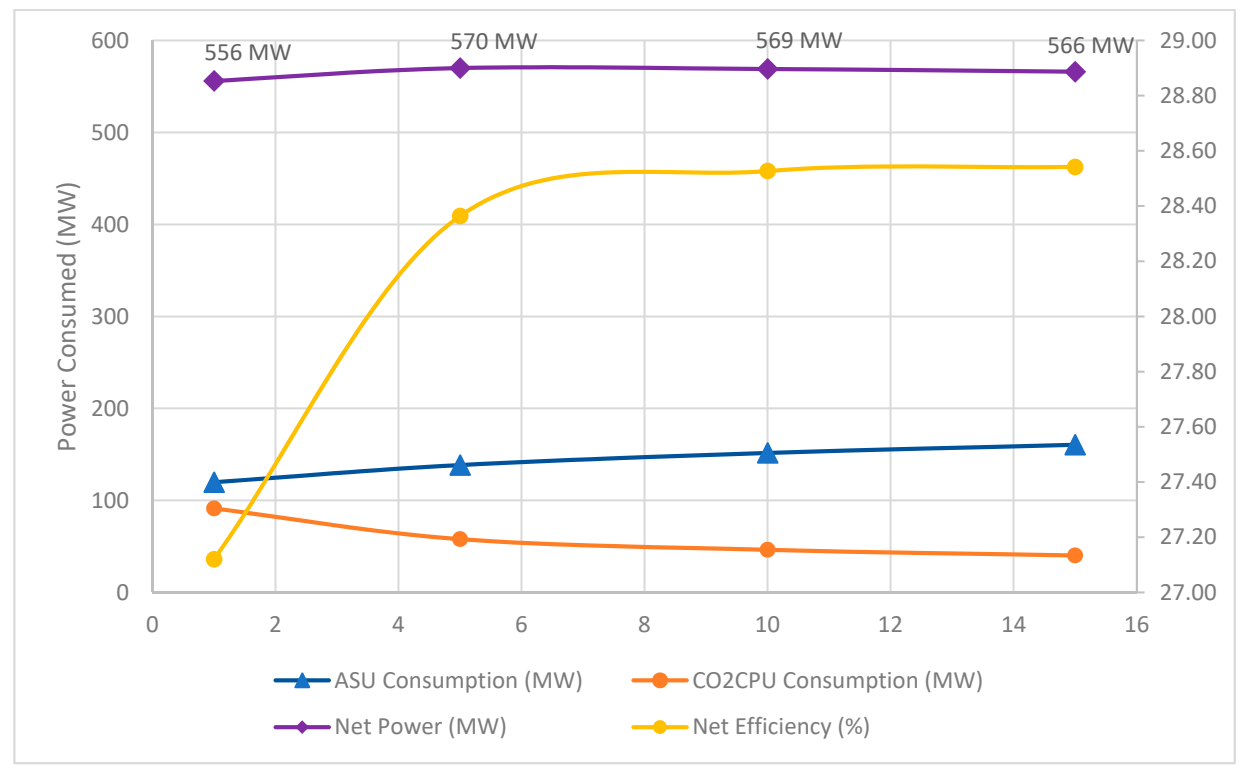

Figure 4. Power consumption of $\mathrm{ASU}$ and $\mathrm{CO}_{2} \mathrm{CPU}$, net power and plant efficiency with varying operating pressure, case for AFT of $1866^{\circ} \mathrm{C}$. Constant gross power of $792 \mathrm{MW}$. 
Increasing the operating pressure increases the power requirement of the ASU due to additional compression requirement for the $\mathrm{O}_{2}$ stream. On the other hand, the $\mathrm{CO}_{2} \mathrm{CPU}$ requires fewer compressors since the flue gas enters at an already elevated pressure. According to Figure 4, the net efficiency increases as the pressure increases above 1 bar, but appears to reach a plateau of $\sim 28.5 \%$ at 10 bars. At a constant gross power, the net power output goes through a maximum between 5 and 10 bars. The overall conclusion from Figure 4 is that operating at 10 bars offers conditions of both high net power and high net efficiency.

\subsection{Economic Evaluation}

The economic model was used to assess operation in the USA and the KSA. Primarily, as mentioned previously, the differences will be due to the cost of raw materials, labour and the discount rate (shown in Table 2). Furthermore, the effect of varying pressure will be similar in both regions; hence, the differences in total investment and operating costs with pressure is only shown for USA.

\subsubsection{Economic Analysis of Oxy-Petcoke Power Plant in the USA}

The economics of oxy-petcoke combustion were studied over various pressures $(1,5,10$ and 15 bars). It should be noted that changing the operating pressure can change both the total capital cost and the cost of manufacturing (COM). Table 5 shows costing of oxy-petcoke plant at different operating pressures. The total capital cost is the sum of all the bare module costs and the other indirect costs associated with the installation of equipment.

Table 5. Economic model results for oxy-petcoke plant at different pressures in the USA.

\begin{tabular}{|c|c|c|c|c|}
\hline Parameter & 1 bar & 5 bars & 10 bars & 15 bars \\
\hline Total Capital Cost (million USD) & 1545.9 & 1433.7 & 1417.1 & 1428 \\
\hline \multicolumn{5}{|l|}{ Bare Module Cost (million USD) } \\
\hline CBS & 267.3 & 205.7 & 215 & 209.5 \\
\hline ASU & 451.6 & 463.4 & 470 & 492.5 \\
\hline $\mathrm{BOP}$ & 51.3 & 51.3 & 51.3 & 51.3 \\
\hline $\mathrm{CO}_{2} \mathrm{CPU}$ & 93.9 & 83.6 & 54.6 & 44.1 \\
\hline Cost of Manufacturing (COM) (million USD) & 486.9 & 405.4 & 407.2 & 411.1 \\
\hline Operating Labour $\left(C_{O L}\right)$ & 1.12 & 1.12 & 1.12 & 1.12 \\
\hline Utilities $\left(C_{O L}\right)$ & 26.3 & 24.4 & 24.1 & 24.3 \\
\hline Waste Treatment $\left(C_{O L}\right)$ & 21.6 & 21.1 & 20.4 & 20.2 \\
\hline Raw Materials $\left(C_{R M}\right)$ & 0 & 0 & 0 & 0 \\
\hline LCOE (cent/kWh) & 10.45 & 9.45 & 9.37 & 9.43 \\
\hline Cost of $\mathrm{CO}_{2}$ Avoided (USD/tonne) & 78.32 & 66.1 & 65.13 & 65.97 \\
\hline Cost of $\mathrm{CO}_{2}$ Capture (USD/tonne) & 53.86 & 45.46 & 44.79 & 45.37 \\
\hline
\end{tabular}

The majority of the equipment cost comes from the ASU and the CBS followed by the $\mathrm{CO}_{2} \mathrm{CPU}$ and BOP. Variations in the operating pressure lead to changes in total cost of only the CBS, ASU and $\mathrm{CO}_{2} \mathrm{CPU}$ sections. Where the CBS experiences changes in only equipment sizing, the ASU and $\mathrm{CO}_{2} \mathrm{CPU}$ sections experience changes in equipment sizing as well as the number of compressors used. With increasing pressure, compressors need to be added to the ASU and correspondingly removed from the $\mathrm{CO}_{2} \mathrm{CPU}$. Generally, increasing pressure results in reduced equipment size and increased wall thickness. Hence, pressure allowance for equipment cost comes from two sources: one is the size of the equipment and the other is a pressure factor for the wall thickness of the equipment (details in [20]). For the combustor in the CBS (responsible for major costs in that section), the wall thickness pressure factor has a moderate effect on cost up to 10 bars, but its effect increases notably above 10 bars [20]; therefore, the reduction in total capital cost up to 10 bars is mostly due to a decrease in equipment size. However, further increases in pressure (beyond 10 bars) increases the cost because of additional cost related to much thicker equipment walls. The non-linear trend in the cost of the CBS section is due to the cost of the flash vessel ' $\mathrm{V}-104$ ', which, in the operating pressure range (1-15 bars), faces cost 
changes because of vessel size and vessel wall thickness. Hence, the reduction in cost due to vessel size is offset by an increase in cost due to vessel wall thickness. Since the correlations for cost and size, and cost and wall thickness are non-linear, the effect of increasing pressure on the total cost of the vessel is non-linear.

The change in cost of the ASU and $\mathrm{CO}_{2} \mathrm{CPU}$ is primarily due to the addition and removal of equipment rather than changes in equipment size. Since compressors are added to the ASU with increasing pressure, its cost increases. Likewise, since compressors and heat exchangers are removed from the $\mathrm{CO}_{2} \mathrm{CPU}$ at high pressures, its cost decreases.

It is clear from Table 5 that high-pressure operation (10-15 bars) is desirable as the lowest costs are all found at 10 bars. The lowest LCOE cost of 9.37 cent/kWh is achieved at 10 bars. Furthermore, at 10 bars, the cost of the $\mathrm{CO}_{2}$ avoided is $65.13 \mathrm{USD} /$ tonne versus $65.97 \mathrm{USD} /$ tonne at 15 bars; and the cost of capturing $\mathrm{CO}_{2}$ is $44.79 \mathrm{USD} /$ tonne compared to $45.37 \mathrm{USD} /$ tonne at 15 bars. These values are within $2 \%$ of each other, and given the similar LCOE value, it means that operating between 10 and 15 bars should be economically optimal for an oxy-petcoke power plant built in the USA.

\subsubsection{Economic Analysis of Oxy-Petcoke Plant in the KSA}

Assumptions pertaining to cost of labour, electricity, and interest rate are given in Table 2. These assumptions do not change the total capital cost of the plant, hence total capital cost is not reported here, as it is the same as that of a plant in the USA. However, the cost of manufacturing (COM) will change due to the change in cost of operating labour $\left(C_{O L}\right)$; which in turn will change $L C O E, L C O E^{\prime}$, cost of $\mathrm{CO}_{2}$ captured, and cost of $\mathrm{CO}_{2}$ avoided (see Equations (1)-(4)). Therefore, data pertaining to only $L C O E$, and cost of $\mathrm{CO}_{2}$ avoided and captured are reported in this section (Table 6).

Table 6. Economic model results for oxy-petcoke plant at different pressures in the KSA.

\begin{tabular}{ccccc}
\hline Parameter & $\mathbf{1}$ bar & $\mathbf{5}$ bars & $\mathbf{1 0}$ bars & $\mathbf{1 5}$ bars \\
\hline $\boldsymbol{L C O E}$ (cent/kWh) & 6.64 & 5.91 & 5.87 & 5.91 \\
Cost of $\mathbf{C O}_{\mathbf{2}}$ Avoided (USD/tonne) & 31.9 & 23.04 & 22.57 & 23.08 \\
Cost of $\mathrm{CO}_{\mathbf{2}}$ Capture (USD/tonne) & 21.94 & 15.85 & 15.52 & 15.87 \\
\hline
\end{tabular}

As was the case in the USA, the lowest $L C O E$, as well as the lowest costs of $\mathrm{CO}_{2}$ avoided and captured are found for an operating pressure of 10 bars. However, the costs are lower for the KSA because of lower discount rate and cost of labour (see Table 2). For example, at 10 bars, LCOE decreases by $\sim 37 \%$ in the case of the KSA compared to that of the USA, and costs of $\mathrm{CO}_{2}$ avoided and captured decrease by $\sim 65 \%$.

Since the costs ( $\mathrm{CCOE}, \mathrm{CO}_{2}$ captured and avoided) are lowest for operation at 10 bars, sensitivity analysis was performed at 10 bars. Figures 5 and 6 show the effect of total capital cost, cost of raw material and cost of labour on LCOE and cost of $\mathrm{CO}_{2}$ avoided for the USA. Note that in the case of petcoke price, the sensitivity analysis was performed using an absolute change in cost (from 0 to 50 $\mathrm{USD} /$ tonne [33]) rather than percentage change in cost.

Figures 5 and 6 are sensitivity plots and show that percentage changes in the operating labour, waste treatment and utilities costs have an insignificant effect on the $L C O E$ and cost of $\mathrm{CO}_{2}$ avoided. Compared to other costs (total capital cost and raw material), these costs are small and hence they do not have a substantial effect. Figure 5 shows that the percentage change in LCOE increases linearly with the absolute cost of petcoke. At a cost of $50 \mathrm{USD} /$ tonne, the $L C O E$ increases by $22.6 \%$, i.e., from 9.4 to 11.5 cent/kWh. Figure 6 shows that the absolute cost of petcoke does not affect the cost of $\mathrm{CO}_{2}$ avoided. This is because $L C O E$ and $L C O E^{\prime}$ increase by the same factor when the cost of petcoke is increased, therefore the changes cancel each other (see Equation (3)). 


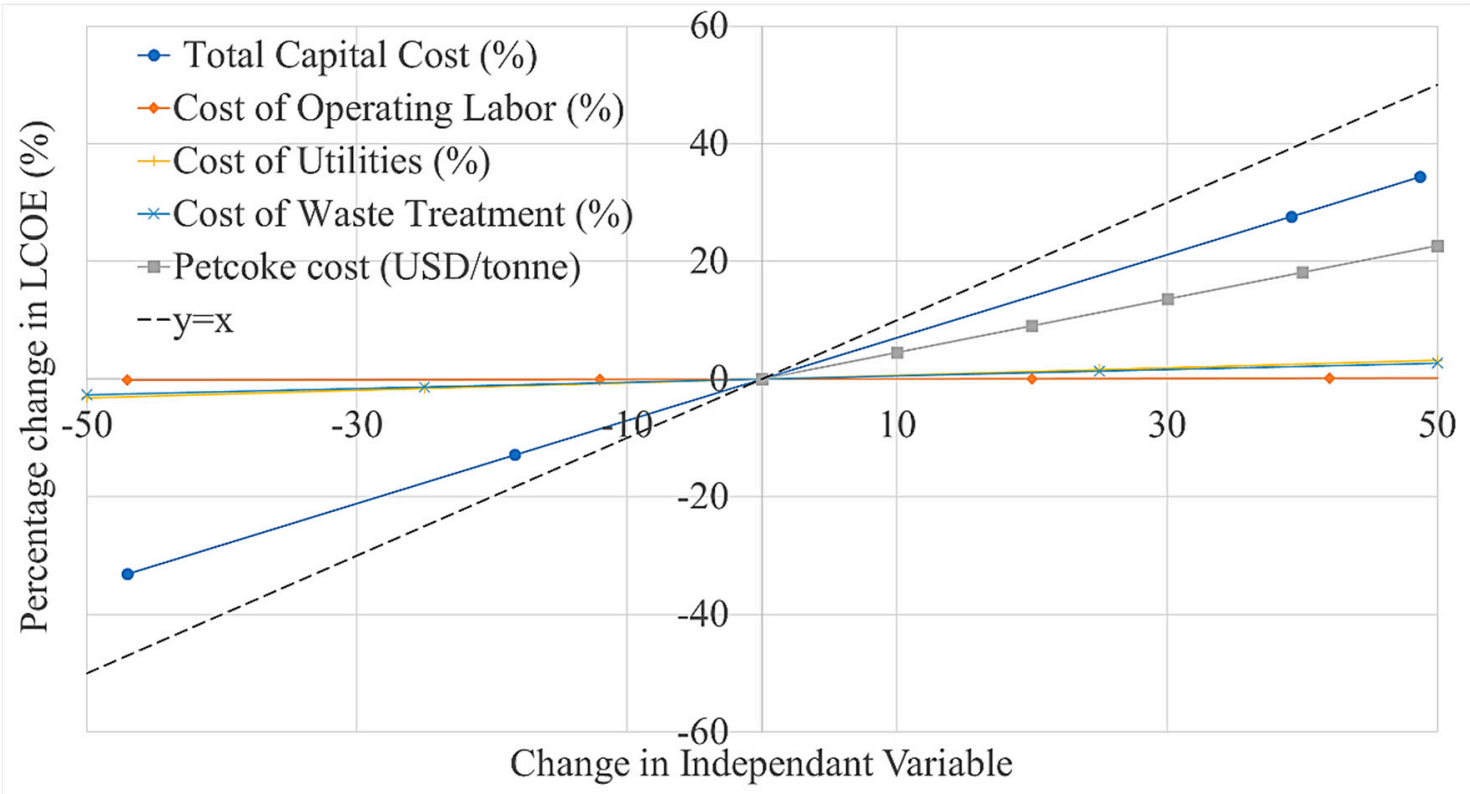

Figure 5. Sensitivity analysis for $L C O E$ in the USA.

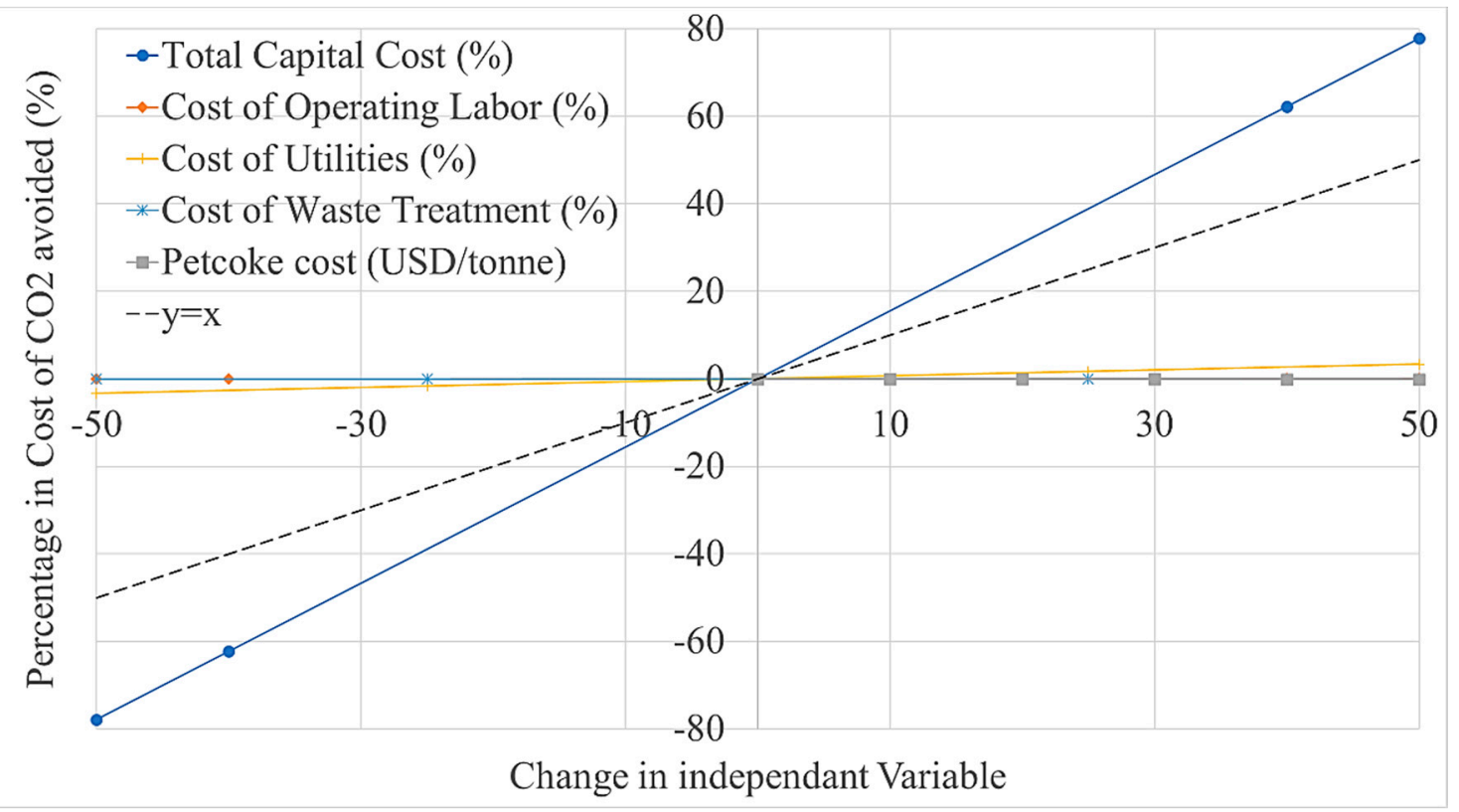

Figure 6. Sensitivity analysis for cost of $\mathrm{CO}_{2}$ avoided in the USA.

\section{Conclusions}

The main conclusions for this work are summarized below (recalling that the basis for all simulation is a constant gross power of $792 \mathrm{MW})$ :

1. There appears to be an optimum pressure (at $\sim 10$ bars) which maximizes the plant efficiency, plant net power output, and minimizes the $L C O E$, cost of $\mathrm{CO}_{2}$ avoided and cost of $\mathrm{CO}_{2}$ captured for both the USA and KSA scenarios. This is due to reduced overall power consumption at high pressure. When the pressure is increased, there is a power balance between ASU and $\mathrm{CO}_{2} \mathrm{CPU}$. The reduction in $\mathrm{CO}_{2} \mathrm{CPU}$ power requirement is higher than the increase in ASU power requirement for operating pressure above 1 bar. 
2. A sensitivity analysis shows that the LCOE moderately increases when increasing the capital cost of the plant $(\sim 0.7 \%$ per $\%$ ) and the cost of petcoke ( $\sim .5 \%$ per USD/tonne), but is insensitive to the costs of labour, utilities and waste treatment.

3. Costs are lower for the KSA scenario because of the lower interest rate and cost of labour.

Oxy-fuel combustion of petcoke is not as efficient as that of coal $(27.1 \%$ net efficiency for petcoke vs. $28.9 \%$ for coal at 1 bar), but leads to higher net power output, the reason being that petcoke oxy-combustion requires lower $\mathrm{ASU}$ and $\mathrm{CO}_{2} \mathrm{CPU}$ duties than in the case of coal.

Supplementary Materials: The following are available online at http://www.mdpi.com/1996-1073/13/13/3463/s1, Figure S-1: Aspen Plus simulation flowsheet of the ASU, Figure S-2: Aspen Plus simulation flowsheet of the BOP, Figure S-3: Aspen Plus simulation flowsheet of the $\mathrm{CO}_{2} \mathrm{CPU}$, Table S-1: Equipment description and material of construction for ASU, CBS, BOP and $\mathrm{CO}_{2} \mathrm{CPU}$.

Author Contributions: Conceptualization, S.M.S. and R.W.D.; methodology, H.H., E.C. and P.L.D.; software, H.H. and S.Y.T.; formal analysis, H.H. and S.Y.T.; investigation, H.H. and S.Y.T.; resources, E.C. and P.L.D.; writing-original draft preparation, S.Y.T. and E.C.; writing-review and editing, P.L.D. and S.M.S.; visualization, H.H. and S.Y.T.; supervision, E.C. and P.L.D.; project administration, S.M.S., R.W.D., E.C. and P.L.D.; funding acquisition, S.M.S. and R.W.D. All authors have read and agreed to the published version of the manuscript.

Funding: This research was funded by the International Partnership for Carbon Neutral Combustion (IPCNC) program, King Abdullah University of Science and Technology (KAUST).

Conflicts of Interest: The authors declare no conflict of interest. The funders had no role in the design of the study; in the collection, analyses, or interpretation of data; in the writing of the manuscript, or in the decision to publish the results.

\section{References}

1. Stockman, L. Petroleum Coke: The coal hiding in the Tar Sands. Oil Chang. Int. 2013. Available online: http://priceofoil.org/content/uploads/2013/01/OCI.Petcoke.FINALSCREEN.pdf (accessed on 1 July 2020).

2. The Engineering ToolBox(2003) Fuels-Higher and Lower Calorific Values. Available online: https: //www.engineeringtoolbox.com/fuels-higher-calorific-values-d_169.html (accessed on 11 January 2020).

3. IPCC. IPCC Special Report on Carbon Dioxide Capture and Storage; Metz, B., Davidson, O., de Coninck, H.C., Loos, M., Meyer, L.A., Eds.; Prepared by Working Group III of the Intergovernmental Panel on Climate Change; Cambridge University Press: Cambridge, UK; New York, NY, USA, 2005; p. 442.

4. Chen, L.; Yong, S.Z.; Ghoniem, A.F. Oxy-fuel combustion of pulverized coal: Characterization, fundamentals, stabilization and CFD modeling. Prog. Energy Combust. Sci. 2012, 38, 156-214. [CrossRef]

5. Uchida, T.; Goto, T.; Yamada, T.; Kiga, T.; Spero, C. Oxyfuel combustion as $\mathrm{CO}_{2}$ capture technology advancing for practical use - Callide oxyfuel project. Energy Procedia 2013, 37, 1471-1479. [CrossRef]

6. Guedea, I.; Lupiañez, C.; Romeo, L.M. Exergetic comparison of different oxyfuel technologies. Int. J. Energy Environ. Eng. 2011, 2, 35-47.

7. Fu, C.; Gundersen, T. Exergy analysis and heat integration of a coal-based oxy-combustion power plant. Energy Fuels 2013, 27, 7138-7149. [CrossRef]

8. Hong, J.; Field, R.; Gazzino, M.; Ghoniem, A.F. Operating pressure dependence of the pressurized oxy-fuel combustion power cycle. Energy 2010, 35, 5391-5399. [CrossRef]

9. Zebian, H.; Gazzino, M.; Mitsos, A. Multi-variable optimization of pressurized oxy-coal combustion. Energy 2012, 38, 37-57. [CrossRef]

10. Soundararajan, R.; Gundersen, T. Coal based power plants using oxy-combustion for $\mathrm{CO}_{2}$ capture: Pressurized coal combustion to reduce capture penalty. Appl. Therm. Eng. 2013, 61, 115-122. [CrossRef]

11. Gopan, A.; Kumfer, B.M.; Phillips, J.; Thimsen, D.; Smith, R.; Axelbaum, R.L. Process design and performance analysis of a Staged, Pressurized Oxy-Combustion (SPOC) power plant for carbon capture. Appl. Energy 2014, 125, 179-188. [CrossRef]

12. Chen, S.; Yu, R.; Soomro, A.; Xiang, W. Thermodynamic assessment and optimization of a pressurized fluidized bed oxy-fuel combustion power plant with $\mathrm{CO}_{2}$ capture. Energy 2019, 175, 445-455. [CrossRef]

13. Shi, Y.; Zhong, W.; Shao, Y.; Liu, X. Energy efficiency analysis of pressurized oxy-coal combustion system utilizing circulating fluidized bed. Appl. Therm. Eng. 2019, 150, 1104-1115. [CrossRef] 
14. Hagi, H.; Nemer, M.; Le Moullec, Y.; Bouallou, C. Pathway for advanced architectures of oxy-pulverized coal power plants: Minimization of the global system exergy losses. Energy Procedia 2013, 37, 1331-1340. [CrossRef]

15. Shafeen, A. An Exergy-Based Framework for Efficiency Improvement for Integrated Oxy-Fuel Power Generation Systems with CO2 Capture; University of Waterloo: Waterloo, ON, Canada, 2014.

16. Chen, H.T.; Wei, W. Efficiency enhancement of pressurized oxy-coal power plant with heat integration. Int. J. Energy Res. 2015, 39, 256-264. [CrossRef]

17. DOE/NETL-2010/1405. Advancing Oxycombustion Technolgoy For Bituminous Coal Power Plants: An R\&D Guide, Final Report, April 2012. Available online: https:/www.netl.doe.gov/projects/files/ AdvancingOxycombustionTechnologyforBituminousCoalPowerPlantsAnRDGuide_040112.pdf (accessed on 1 July 2020).

18. Zanganeh, K.; Shafeen, A. Auto-Refrigerated Gas Separation System for Carbon Dioxide Capture and Compression. U.S. Patent Application 13/389, 2011.

19. Towler, G.; Sinnot, R. Chemical Engineering Design Principles, Practice, and Economics of Plant and Process Design, 1st ed.; Butterworth-Heinemann: Oxford, UK, 2008.

20. Turton, R.; Bailie, R.; Whiting, W.; Shaeiwitz, J. Analysis, Synthesis, and Design of Chemical Processes, 3rd ed.; Prentice Hall: Upper Saddle River, NJ, USA, 2009.

21. Raibhole, V.N.; Sapali, S.N. Simulation and Parametric Analysis of Cryogenic Oxygen Plant for Biomass Gasification. Mech. Eng. Res. 2012, 2, 97. [CrossRef]

22. Fu, Q.; Zhu, L.; Chen, X. Complete Equation-Oriented Approach for Process Analysis and Optimization of a Cryogenic Air Separation Unit. Ind. Eng. Chem. Res. 2015, 54, 12096-12107. [CrossRef]

23. Alfred ong'iro, V.; Ismet Ugursal, A.M.; Al Taweel, G.L. Simulation of Combined Cycle Power Plants. Response 1995, 15, 105-113.

24. Nazir, S.M.; Bolland, O.; Amini, S. Analysis of combined cycle power plants with chemical looping reforming of natural gas and pre-combustion $\mathrm{CO}_{2}$ capture. Energies 2018, 11, 147. [CrossRef]

25. Nayak, R.; Mewada, R. Simulation of Coal Gasification Process using ASPEN PLUS. In Proceedings of the International Conference On Current Trends in Technology, Ahmedabad, India, 8-10 December 2011.

26. AspenPlus Aspen Plus 2004.1: Getting Started Modeling Processes with Solids. 2004. Available online: https: //www.coursehero.com/file/39509450/AspenPlus2004-Gettingstartedwithsolidspdf/ (accessed on 1 July 2020).

27. Buhre, B.J.P.; Elliott, L.K.; Sheng, C.D.; Gupta, R.P.; Wall, T.F. Oxy-fuel combustion technology for coal-fired power generation. Prog. Energy Combust. Sci. 2005, 31, 283-307. [CrossRef]

28. Kanniche, M.; Gros-Bonnivard, R.; Jaud, P.; Valle-Marcos, J.; Amann, J.M.; Bouallou, C. Pre-combustion, post-combustion and oxy-combustion in thermal power plant for CO2 capture. Appl. Therm. Eng. 2010, 30, 53-62. [CrossRef]

29. Rubin, E.S.; Davison, J.E.; Herzog, H.J. The cost of CO2 capture and storage. Int. J. Greenh. Gas Control 2015, 40, 378-400. [CrossRef]

30. IEA Greenhouse Gas R\&D Programme (IEA GHG), “CO2 Capture in Low Rank Coal Power Plants, January 2006. Available online: https://www.google.com.hk/url?sa=t\&rct=j\&q=\&esrc=s\&source=web\&cd=\&cad= rja\&uact=8\&ved=2ahUKEwiVqpn7yLLqAhWQFogKHWNICO4QFjAAegQIBRAB\&url=http\%3A\% 2F\%2Fieaghg.org\%2Fdocs\%2FGeneral_Docs\%2FReports\%2F2006-1\%2520Low\%2520rank\%2520coal\% 2520report.pdf\&usg=AOvVaw2m9E-fZVNI_owdmWx_I82H (accessed on 1 July 2020).

31. Doing Business in the Kingdom of Saudi Arabia: A Tax and Legal Guide. Available online: https: //www.pwc.com/m1/en/tax/documents/doing-business-guides/doing-business-guide-ksa-2020.pdf (accessed on 1 July 2020).

32. U.S Bureau of Labor Statistcs Occupational Employment Statistics. Available online: https://www.bls.gov/ oes/current/oes518013.htm (accessed on 1 July 2020).

33. EIA. Electric Power Mothly; EIA: Washington, DC, USA, 2018.

(C) 2020 by the authors. Licensee MDPI, Basel, Switzerland. This article is an open access article distributed under the terms and conditions of the Creative Commons Attribution (CC BY) license (http://creativecommons.org/licenses/by/4.0/). 